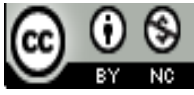 \\ Jurnal Terapan Manajemen dan Bisnis is licensed under \\ A Creative Commons Attribution-Non_Commercial 4.0 International License.
}

\section{POPULAR LEADERSHIP STYLE IN LOCAL BUREAUCRACY}

\author{
Erika Juniar1), Singgih Tiwut Atmojo ${ }^{2)}$, Liza Aswati ${ }^{3)}$
}

1) STIE Mulia Singkawang, Singkawang, Indonesia E-mail: juniarerika@gmail.com

2) STIE Mulia Singkawang, Singkawang, Indonesia E-mail: singgihatdmodjo3805@gmail.com

3) STIE Mulia Singkawang, Singkawang, Indonesia E-mail: alongtedi@gmail.com

\begin{abstract}
The purpose of this study was to find leadership style popular (autocratic, laissezfaire, paternalistic, charismatic and democratic) on employee work discipline at Dinas Lingkungan Hidup Singkawang City. In this study, using a form of qualitative research. The method of data collection consisted of primary data (observations, and questionnaires). The population of this study was the employes in Dinas Lingkungan Hidup Singkawang City, and the sample is all populations made into samples. This study concluded that together or simultaneously leadership style has an influence on employee work discipline of the Dinas Lingkungan Hidup Singkawang City, with a significance of $0.004<0.05$. Four of the five independent variables proved influential on work discipline, the variable is autocratic, laissez-faire, charismatic, and democratic. The conclusion of this study was that what was felt by employees of Dinas Lingkungan Hidup Singkawang City that the popular leadership style in their opinion was style autocratic, laissez-faire, charismatic and democratic style.
\end{abstract}

Keywords: Leadership Style; Local Bureaucracy; Work Discipline

\title{
Introduction
}

Dinas Lingkungan Hidup Singkawang City is one type of public organization where normatively a government organization is given the power to run a government to serve the interests of the people as one of its main tasks. In carrying out these tasks a government must base on the applicable laws and regulations in order to achieve work discipline in the process of implementation. Based on this thought that the performance and discipline of employees at Dinas Lingkungan Hidup Singkawang City has been standardized and regulated in the law in the hope that the binding and generally accepted regulations of employees must obey and discipline behavior both in carrying out work, completing work and with regard to the most basic things namely hours of entry and return to work and absenteeism. Work discipline is one of the important functions of human resource management and is the key to the realization of goals because without discipline it is difficult to realize maximum goals (Sedarmayanti, 2010). Rivai (2010), work discipline is a tool used by managers to communicate with employees so that they are willing to change behavior and as an effort to 
increase one's awareness and willingness to observe all company regulations and applicable social norms. Further work discipline can be done by giving sanctions in the form of penalties and reprimands in order to create a deterrent effect for employees and so that employees do not repeat their mistakes again and can work better (Prawira Jaya \& Adyani, 2015). Therefore employee work discipline has a very important influence in realizing the effective performance of quality human resources.

The inculcation of the values of discipline can develop if it is supported by a conducive environmental situation as stated by (Tohardi, 2016), which is between the situation and the consistent treatment of leaders and employees. With an attitude of mutual respect for each other will make employees responsible for themselves, their work and their environment in achieving their ideals and goals and being able to maintain the stability of agencies and standards that apply in the agency. Indicators of work discipline refer to two aspects, namely personality and environmental factors (Helmi,1996). Personal factors include the level of attendance, discipline measured according to the frequency level of absenteeism. Because, the higher the frequency of attendance or the low level of absenteeism, the employee has a high work discipline. Based data employee absence Dinas Lingkungan Hidup Singkawang City 2017 can be seen from the first quarter to the fourth quarter the absentee level has fluctuations or different increases and decreases. The causes of the high increase in employee absenteeism at the Dinas Lingkungan Hidup Singkawang City, which is due to a large number of female employees in the Dinas Lingkungan Hidup Singkawang City, are 19 people out of 40 employees. Where female employees have more opportunities to take leave or permission, for reasons of childbirth and menstruation. In the case of absenteeism and change or discharge from work, women are still higher than men.

The second factor is environmental factors, high work discipline does not just appear but rather the results of a continuous learning process. The learning process to be effective, leaders who are agents of change must be able to apply the principles of consistency, fairness, positive and open These principles refer to the model or type of leadership style that is applied. A good leader will be able to apply various leadership styles to suit the environment, the situation of the subordinates. Like applying a fair concept, it means that a leader must be fair, not discriminating against all subordinates, judgments are not based on likes and dislike or are always consistent with regulations from time to time, once the rules are violated the sanctions and laws are clear without dispensation.

Thoha (2015) states that leadership style is the norm of behavior used by someone when that person tries to influence the behavior of others as he sees it. Thoha (2015) that the Path Goal theory seeks to explain the influence of leader behavior on the motivation, satisfaction, and implementation of the work of his subordinates. Dewi's research (2012) explains that the Path Goal theory divides four leadership styles namely directive leadership, supportive leadership, participatory leadership, and achievement-oriented leadership. Applying the four leadership approaches can improve employee performance and also later increase employee motivation and discipline. Rivai (2010) Leadership style can be defined as behavior and strategy as a result of a combination of the philosophy, skills, traits, and attitudes that are often applied by a leader when he tries to influence the performance of his subordinates. Types of leadership styles include autocratic, laissez-faire, paternalistic, charismatic, and democratic (Siagian, 2010). The leader has a very important role in upholding the discipline of an institution or organization. A leader is someone who has the ability to influence others to be able to do things according to their wishes and in accordance with organizational goals. Leadership is not only meant to influence someone to achieve goals but also is a process of motivating employee behavior in efforts to improve the group 
and work discipline of company employees. The function of the leadership style has a direct relationship that is closely related to the social situation in the life of the group or organization, which implies that every leader is in the situation. Rivai (2010) stated that there are five main functions of leadership, i.e. instruction, consultation, participation, delegation, and control.

Refer to environmental factors by considering the importance of the leader's influence in directing the bottom consisting of a variety of different individuals in achieving organizational goals. Leaders as role models for employees have a role in influencing their employees. In addition, with the various types of leadership styles, the writer is interested in seeing which leadership style is most popular or desired by employees by comparing various leadership styles to employee work discipline. Based on this explanation the authors make the research title "Popular Leadership Styles in Local Bureaucracy". From the background above, the hypothesis can be formulated:

$\mathrm{H1}$ : Autocratic $\left(\mathrm{X}_{1}\right)$ influences employee work discipline $(\mathrm{Y})$ in Dinas Lingkungan Hidup Singkawang City

H2 : Laissez-Faire $\left(\mathrm{X}_{2}\right)$ influences employee work discipline $(\mathrm{Y})$ in Dinas Lingkungan Hidup Singkawang City

H3 : Paternalistic $\left(\mathrm{X}_{3}\right)$ influences employee work discipline $(\mathrm{Y})$ in Dinas Lingkungan Hidup Singkawang City

H4 : Charismatic $\left(\mathrm{X}_{4}\right)$ influences employee work discipline $(\mathrm{Y})$ Dinas Lingkungan Hidup Singkawang City

H5 : Democratic $\left(X_{5}\right)$ influences employee work discipline $(Y)$ in Dinas Lingkungan Hidup Singkawang City

H6 : Autocratic $\left(X_{1}\right)$, Laissez-Faire $\left(X_{2}\right)$, Paternalistic $\left(X_{3}\right)$, Charismatic $\left(X_{4}\right)$, and Democratic $\left(\mathrm{X}_{5}\right)$ simultaneously influence employee work discipline $(\mathrm{Y})$ in Dinas Lingkungan Hidup Singkawang City

\section{Research Methods}

The research method is using qualitative research by using descriptive methods. The population of this study was 40 people and the sample is all populations made into samples, sample collection techniques using a census. Variables in this study include dependent variables are work discipline $(\mathrm{Y})$, while independent variables are autocratic leadership style $\left(X_{1}\right)$, laissez-faire $\left(X_{2}\right)$, paternalistic $\left(X_{3}\right)$, charismatic $\left(X_{4}\right)$, democratic $\left(X_{5}\right)$. Measurement of variables using Likert's scale. Data collection techniques using this study are questionnaires and observation.

To test the hypothesis in this study used a multiple linear regression analysis models. In this analysis, several models of leadership style include autocratic $\left(X_{1}\right)$, laissez-faire $\left(X_{2}\right)$, paternalistic $\left(\mathrm{X}_{3}\right)$, charismatic $\left(\mathrm{X}_{4}\right)$, and democratic $\left(\mathrm{X}_{5}\right)$ affect work discipline $(\mathrm{Y})$. The testing procedure for each hypothesis starts with a partial test (regression coefficient) or called a ttest. The hypothesis in the t-test is H0, which means that there is no significant effect on $\mathrm{Y}$, whereas $\mathrm{H} 1$ means that variable $\mathrm{X}$ has a significant effect on $\mathrm{Y} . \mathrm{H} 0$ is rejected and $\mathrm{H} 1$ is accepted if the value of $t$ counts more than $t$ table ( $t$-count $>t$-tab). In the analysis and regression test, this is done using SPSS 25 for Windows. Against variables, correlation analysis is carried out to determine the shape and strength of the relationship of independent variables to the dependent variable. 
Results and Discussion

A. Validity Test

Table 1 Validity Test Result

\begin{tabular}{cccccccc}
\hline $\mathbf{X}_{\mathbf{1}}$ & $\mathbf{X}_{\mathbf{2}}$ & $\mathbf{X}_{\mathbf{3}}$ & $\mathbf{X}_{\mathbf{4}}$ & $\mathbf{X}_{\mathbf{5}}$ & $\mathbf{Y}$ & Sig. & Description \\
\hline 0.001 & 0.000 & 0.000 & 0.000 & 0.000 & 0.000 & 0.05 & Valid \\
0.017 & 0.000 & 0.000 & 0.000 & 0.000 & 0.000 & 0.05 & Valid \\
0.000 & 0.000 & 0.000 & 0.000 & 0.000 & 0.000 & 0.05 & Valid \\
0.000 & 0.000 & 0.000 & 0.000 & 0.000 & 0.000 & 0.05 & Valid \\
\hline
\end{tabular}

Based on Table 1 the results of the validity test are declared valid because the value of all indicators on the variable shows a significance value below 0.05 .

B. Reliability Test

Table 2 Reliability Test Result

\begin{tabular}{lcc}
\hline \multicolumn{1}{c}{ Variables } & Cronbach's Alpha & Description \\
\hline Autocratic (X1) & 0.723 & Reliable \\
Laissez Faire (X2) & 0.776 & Reliable \\
Paternalistic (X3) & 0.799 & Reliable \\
Charismatic (X4) & 0.733 & Reliable \\
Democratic (X5) & 0.814 & Reliable \\
Work Discipline (Y) & 0.822 & Reliable \\
\hline
\end{tabular}

Table 2 test results show Cronbach's Alpha value of all variables is greater than 0.600 , it can be concluded that all question items are reliable because all question items have Cronbach's Alpha values above 0.600 .

\section{Classic Assumption Test}

The classic assumption test is carried out to obtain an unbiased and efficient estimator value from the regression equation with the ordinary least square method. Therefore, in the implementation of data analysis must meet the classical assumptions. Testing the regression model includes the assumption of normality, multicollinearity, heteroscedasticity, and autocorrelation. The description of the calculation testing the assumption of the regression model can be explained.

The normality test uses a graphical normal probability plots method that is used to determine whether in a regression model, the residual regression value is normally distributed or not. A good regression model should be a normal or near a normal residual regression distribution. To find out the results of the residual normality test can be seen in Fig. 1. 


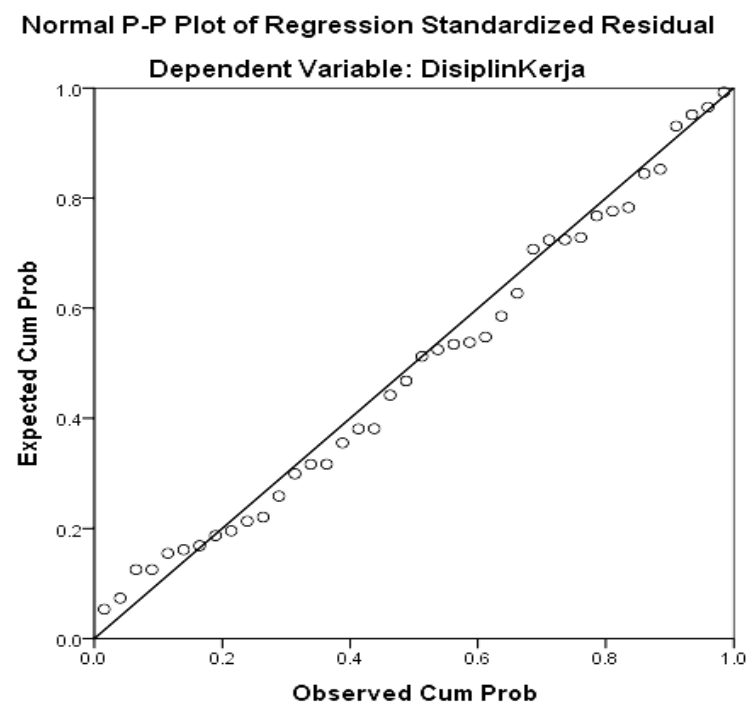

Fig. 1 PP-Plot Normality Test

The basis for decision making to detect normality is if the data spread around the diagonal line and follows the diagonal direction, then the residual is normally distributed. The P-P plot view of the Standardized Residual Regression in Figure 1 above shows that the points (which represent the real data) are seen to spread around the diagonal line and follow the direction of the diagonal line. This shows that the regression model is normally distributed.

The multicollinearity test in this study in detecting the presence or absence of multicollinearity can be seen from the Variance Inflation Factor (VIF). If the VIF value is > 10, it indicates multicollinearity. If the opposite is VIF $<10$ then multicollinearity does not occur. For the multicollinearity test in this study, it concludes collinearity of the transformations shows a VIF value of no more than 10, there is no multicollinearity. This heteroscedasticity test uses the Spearman rho method, that is, if the significance value between the independent variables with absolute residuals is more than 0.05 , there is no problem with heteroscedasticity. From the calculation results it is known that the variable significance value $\left(X_{1}\right)$ is $0.210,\left(X_{2}\right)$ 0.874, $\left(X_{3}\right)$ 0.097, $\left(X_{4}\right)$ 0.075, and $\left(X_{5}\right)$ of 0.860 is greater than 0.05 . Because the overall significance value of the variable is more than 0.05 , it can be concluded that in the regression model there is no problem of heteroscedasticity.

The autocorrelation test in this study conducted by examining the presence or absence of autocorrelation in the regression of the dependent variable is done by checking the statistics of Durbin-Watson (DW). It can be seen that Durbin Watson is 1,920 . Whereas from the DW table with a significance of 0.05 and the amount of data $(n)=40$, and the number of independent variables $(\mathrm{k})=5$, obtained a $\mathrm{dL}$ value of 1,231 and $\mathrm{dU}$ of 1,786 . Because $\mathrm{DW}$ $(1,920)$ is in the area between $\mathrm{dU}(1,786)$ and $4-\mathrm{dU}(2,214)$ or $\mathrm{dU}<\mathrm{DW}<4-\mathrm{dU}$, then $\mathrm{H} 0$ is accepted and it can be concluded that there is no autocorrelation problem.

\section{Hypothesis Test Result}

To find out whether the hypothesis proposed in this study is accepted or rejected, it will be tested by using the t-test. The results of hypothesis testing are explained in Table 3 . 
Table 3 The results of Hypothesis Testing

\begin{tabular}{lrc}
\hline \multicolumn{1}{c}{ Variables } & \multicolumn{1}{c}{ T } & \multicolumn{1}{c}{ Sig. } \\
\hline Autocratic $(\mathrm{X} 1)$ & -2.267 & .030 \\
Laissez Faire $(\mathrm{X} 2)$ & 3.317 & .002 \\
Paternalistic $(\mathrm{X} 3)$ & .359 & .722 \\
Charismatic $(\mathrm{X} 4)$ & -2.400 & .022 \\
Democratic $(\mathrm{X} 5)$ & 2.193 & .035 \\
\hline
\end{tabular}

\section{Testing of the first hypothesis}

The test results indicate that the autocratic leadership style is partially stated to have a significant effect on work discipline with a significance level of $0.030<0.05$. Based on the results of this test, it can be concluded that the first hypothesis which states that there is an influence between autocratic leadership style (X1) on work discipline $(\mathrm{Y})$ is proven (accepted). The results of the hypothesis mean that the autocratic leadership style as its meaning is the type of leadership that requires all the policies and decisions of an organization in its hands. This makes the subordinates feel scared and indirectly forces the subordinates to be more disciplined because the subordinates feel they are always supervised where this supervision generally includes supervision of subordinates' attitudes, behaviors, actions or activities that are carried out strictly. This type of leadership also assumes that subordinates are only limited to carrying out tasks or carrying out all orders of superiors that must be obeyed, for subordinates who do not carry out orders or reject orders that they find challenging. in addition, in terms of communication this type of leadership takes place in one direction, subordinates will only be invited to communicate if there is an order or warning. Generally, subordinates are not involved in decision making because all policies have been implemented, regulated and made by superiors. This type of autocratic leadership is rigid but this type of leadership is applied well to make subordinates disciplined because it implies very high discipline. These results are in line with research Leoni (2014) and Prawira Jaya and Adyani (2015) explaining that autocratic style influences work discipline because leaders who apply this leadership style do not force employees to be orderly and work in accordance with the wishes of the leadership.

\section{Testing of the second hypothesis}

The test results show that the laissez-faire leadership style is partially stated to have a significant influence on work discipline with a significance level of $0.002<0.05$. Based on the results of this test, it can be concluded that the second hypothesis which states that there is an influence between laissez-faire leadership style (X2) on work discipline $(\mathrm{Y})$ is proven (accepted). The test results show that the laissez-faire leadership style has a significant influence on work discipline with a significance level of $0.002<0.05$. Based on the results of this test, the leadership style of work discipline $(\mathrm{Y})$ is proven (accepted). This result is supported by previous research conducted by Farida (2007) and Gurning (2013) showing the same results which state that laissez-faire leadership has a significant effect on work discipline, with the conclusion that the more leadership styles are applied, the more work discipline will be encouraged by employees strong to complete the tasks assigned to him responsibly. Laissez-faire leadership requires all components of the education agent to carry out their duties freely. Therefore the type of free leadership is the ability to influence others to want to work together to achieve the goals set by the various activities submitted to subordinates. In this research, leadership tries to give subordinates the freedom to explore their abilities so as to make subordinates work more freely so as to create a comfortable work 
environment. So things like this are wanted even by subordinates. However, the freedom granted is not absolute freedom nor is it given without monitoring because it is feared that freedom given without control and monitoring will cause certain problems that can interfere with organizational stability. For example, in the form of work confusion and arbitrary conflict because each individual has different desires to be carried out so that each of them argues, opposes the strength and strength of battle and unfair competition among subordinates. This is where the important role of leaders to unite, direct, coordinate and move the position down but specifically in the Singkawang City Environment Department the problem did not occur because all employees who worked carrying out their duties, principals and functions in accordance with applicable regulations.

\section{Testing of the third hypothesis}

The test results show that the paternalistic leadership style is partially stated not to have a significant effect on work discipline with a significance level of 0.722 . Based on the test results, it can be concluded that the third hypothesis which states there is an influence between the internal leadership style (X3) on work discipline $(\mathrm{Y})$ is not proven (rejected). This result is supported by previous research conducted by Gurning (2013) which stated that paternalistic leadership style does not significantly influence work discipline with the conclusion that the use of paternalistic leadership can produce optimal work discipline if the leader views employees as adults which means no attention is needed in carrying out the task. By applying this style, employees assume that carrying out tasks with full responsibility does not need to be done because the leadership itself is not concerned with carrying out the tasks performed by employees.

\section{Testing of the four hypothesis}

The test results show that the charismatic leadership style is partially stated to have a significant effect on work discipline with a significance level of 0.022. Based on the results of these tests, it can be concluded that the fourth hypothesis which states that there is an influence between charismatic leadership style $\left(\mathrm{X}_{4}\right)$ on work discipline $(\mathrm{Y})$ is proven (accepted). These results are supported by previous research conducted by Gurning (2013) stated that charismatic leadership styles have a significant effect on work discipline with the conclusion that the use of charismatic leadership styles can produce optimal work discipline through high attractiveness and good impression by the leadership, Leaders emphasize the balance between the implementation of tasks and maintenance of relations with subordinates and subordinates involved in making work decisions, thus leadership is accepted and recognized and respected by the subordinates, which impact on subordinates will be willing to carry out work with full responsibility and comply with established regulations.

\section{Testing of the fifth hypothesis}

The test results show that the democratic leadership style is partially stated to have a significant effect on work discipline with a significance level of 0.035 . Based on the results of these tests, it can be concluded that the fifth hypothesis which states that there is an influence between democratic leadership styles $\left(\mathrm{X}_{5}\right)$ on work discipline $(\mathrm{Y})$ is proven (be accepted). These results are supported by previous research conducted by Farida (2007) and Nurmaladewi (2015) stated that the style of democratic leadership positively influences subordinate work discipline. The style that the more absolute leadership style is applied, the work discipline increases. In this research, the leader views his role as the coordinator and integrator of various elements and organizational components. The leader places himself as 
the controller, regulator, and supervisor of the organization by not obstructing the rights of his subordinates to argue. He also functions as a liaison between departments within an organization where each task and authority of the organizers of the organization are arranged in such a way that it is clear the parts of the duties of each of the administrators, which later will not occur interference between parts of the organization. This result is in line with the position of the Dinas Lingkungan Hidup Singkawang City which is a public organization tasked with providing services to the community and conducting socialization, notification to the public regarding information, regulations relating to public needs (community). The division of tasks carried out at the Dinas Lingkungan Hidup Singkawang City is also very efficient and effective because it is applied in an organization where the main goal of the organization is the achievement of common goals and interests.

\section{Testing of the sixth hypothesis}

The test results show that the leadership style has a significant effect on employee work discipline with a significance of $0.004<0.05$ (Table 4). Based on the results (F Test), it can be concluded that the sixth hypothesis states that there is influence between leadership style (autocratic $\left(X_{1}\right)$, laissez-faire $\left(X_{2}\right)$, paternalistic $\left(X_{3}\right)$, charismatic $\left(X_{4}\right)$, and democratic $\left(X_{5}\right)$ ) on the work discipline of the staff of the Department of Environment of the City of Singkawang $(\mathrm{Y})$ is proven (accepted). The results calculation coefficient of determination ( $\mathrm{R}$ Square) of 0.384 (Table 5). These results indicate that the work discipline of the Department of Environment of Singkawang City was explained by the leadership style variables of $38.4 \%$, while the remaining $61.6 \%$ was influenced by other variables not examined in this study.

Table 4 Test Result Uji F

\begin{tabular}{|c|c|c|c|c|c|c|}
\hline \multicolumn{2}{|c|}{ Model } & Sum of Squares & Df & Mean Square & $\mathbf{F}$ & Sig. \\
\hline 1 & Regression & 25.272 & 5 & 5.054 & 4.243 & $.004^{b}$ \\
\hline & Residual & 40.503 & 34 & 1.191 & & \\
\hline & Total & 65.775 & 39 & & & \\
\hline
\end{tabular}

Table 5 Test Result Determination Coefficient

\begin{tabular}{lcrrr}
\hline \multicolumn{5}{c}{ Model Summary $^{\mathbf{b}}$} \\
\hline Model & R & R Square & Adjusted R Square & Std. Error of the Estimate \\
\hline 1 & $.620^{a}$ & .384 & .294 & 1.091 \\
\hline
\end{tabular}

\section{Conclusion}

The $\mathrm{F}$ test results with a significance of $0.004<0.05$, indicated that simultaneously the leadership style has a positive and significant influence on employee work discipline Dinas Lingkungan Hidup Singkawang City. Based on the results of the t-test, among of the five variables, there were 4 variables that are received or significantly influence namely the autocratic leadership style variable $\left(X_{1}\right)$, laissez-faire $\left(X_{2}\right)$, charismatic $\left(X_{3}\right)$ and the democratic leadership style $\left(X_{5}\right)$ where the four variables showed the value significance below 0.05 . Whereas for the paternalistic leadership style variable the test results showed a significant value above 0.05 , which is equal to 0.722 meaning that it has no significant effect or is rejected. The results calculation coefficient of determination ( $R$ Square) was 0.384 . It means that the influence of independent variables (leadership style) are autocratic leadership style $\left(\mathrm{X}_{1}\right)$, laissez-faire leadership style $\left(\mathrm{X}_{2}\right)$, paternalistic leadership style $\left(\mathrm{X}_{3}\right)$, charismatic leadership style $\left(\mathrm{X}_{4}\right)$, and democratic leadership style $\left(\mathrm{X}_{5}\right)$ on the dependent variable (work discipline) is $38.4 \%$, while the remaining $61.6 \%$ is influenced by other variables. 


\section{Suggestion}

a. For Dinas Lingkungan Hidup Singkawang City

1) Based on the results of data analysis shows that not all leadership styles have a significant influence on employee work discipline. The results of the analysis show that only the external leadership style does not have a significant effect on employee work discipline. That way, the external leadership style is not right or ideal to be applied by leaders in the Dinas Lingkungan Hidup Singkawang City. Leaders with a paternalistic leadership style do not use employees or subordinates as a source of information, ideas, and suggestions. This means subordinates are not encouraged to think innovatively and creatively.

2) The leader should adopt a democratic leadership style because based on the results of the questionnaire recapitulation, the staff at the Dinas Lingkungan Hidup Singkawang City agreed more or liked leaders with a democratic leadership style with an average of 4.67 percent or interpreted very highly because the style of democratic leadership was the style of a leader who respects the characteristics and abilities possessed by each member of the organization and the leader always involves subordinates in decision making when there is a problem and the leader also provides efficient descriptions and guidance about the tasks to be given to his subordinates.

3) Leaders are advised to maintain and improve employee work discipline so that in the future by applying leadership styles that are in accordance with the conditions and environment of the organization, employee discipline will be even better.

b. For Further Researchers

The next researcher can develop this research by examining other factors that can influence employee work discipline, such as motivation, job satisfaction and can even make compensation factors as variables to measure work discipline. because the leadership style factor for work discipline only affects $38.4 \%$, while the remaining $61.6 \%$ is influenced by other variables.

\section{References}

Badan Lingkungan Hidup Kota Singkawang (2017). Buku Laporan Antara Status Lingkungan Hidup Daerah Kota Singkawang. Singkawang.

Dewi, P.S. (2012). Pengaruh Pengendalian Internal dan Gaya Kepemimpinan Terhadap Kinerja Karyawan SPBU Yogyakarta. Jurnal Nominal, 1(1).

Gurning, Citra Rosa A. (2013).Pengaruh Gaya Kepemimpinan Terhadap Disiplin Kerja Pegawai Dinas Kebersihan dan Pertamanan Kota Bogor. Scientific Repository Institut Pertanian Bogor.

Helmi, A.F. (1996). Disiplin Kerja. Buletin Psikologi Tahun 4 No 2 Edisi Khusus Ulang Tahun XXXII. Fakultas Psikologi Universitas Gajah Mada.

Leoni et al. (2014). Gaya Kepemimpinan Otokratis, Demokratis dan Laissez Faire Terhadap Peningkatan Prestasi Kerja Karyawan. Jurnal EMBA, 2(1).

Nurmaladewi, Ragil. (2015). Pengaruh Gaya Kepemimpinan terhadap Disiplin Kerja Pegawai Kelurahan Kemboja KecamatanTanjungpinang Barat. Jurnal Program studi ilmu administrasi Negara Fakultas ilmu sosial dan politik. Universitas Maritim Raja Ali haji Tanjungpinang.

Prawira Jaya, Y.K \& Adyani, D.A.I. (2015). Pengaruh Gaya Kepemimpinan Terhadap Disiplin Kerja Pegawai Dinas Balai Bahasa Provinsi Bali. E-Jurnal Manajemen Universitas Udayana, 4(9). 
Rivai, Veithzal. (2010). Manajemen Sumber Daya Manusia Untuk Perusahaan: Dari Teori ke Praktik. Jakarta: Rajawali Pers.

Sedarmayanti. (2010). Manajemen Sumber Daya Manusia. Bandung: Refika Adiutama.

Setiawan, E. (2018). Pengaruh Gaya Kepemimpinan dan Komitmen Organisasi Terhadap Disiplin Kera dengan Kepuasan Kerja Sebagai Variabel Intervening. Jurnal Prima Ekonomika, 9(1).

Siagian, P.S. (2010). Teori dan Praktek Kepemimpinan. Jakarta: Rineka Cipta.

Susanty, A \& Baskoro, W.S. (2012). Pengaruh Motivasi Kerja dan Gaya Kepemimpinan Terhadap Disiplin Kerja Serta Dampaknya pada Kinerja Karyawan. Jurnal Teknik Industri, 7(2).

Thoha, Miftah. (2015). Kepemimpinan dalam Manajemen. Depok: Rajawali Pers.

Tohardi, A. (2016). Pemahaman Praktis Manajemen Sumber Daya Manusia. Bandung: CV Mandar Maju. 